\title{
NI MYDAQ ESZKÖZZEL TÁMOGATOTT IPARI SZENZOR VIZSGÁLÓ ÁLLOMÁS MODELLEZÉSE
}

\author{
Ács Viktória \\ Villamosmérnöki és Mechatronikai \\ Tanszék \\ Debreceni Egyetem, Müszaki Kar \\ Debrecen, Magyarország \\ acsviktoria6@gmail.com
}

\author{
Dr. Tóth János \\ Villamosmérnöki és Mechatronikai \\ Tanszék \\ Debreceni Egyetem, Müszaki Kar \\ Debrecen, Magyarország \\ tothjanos@eng.unideb.hu
}

\author{
Dr. habil Husi Géza \\ Villamosmérnöki és Mechatronikai \\ Tanszék \\ Debreceni Egyetem, Müszaki Kar \\ Debrecen, Magyarország \\ husigeza@eng.unideb.hu
}

\begin{abstract}
Absztrakt- Munkám célja az volt, hogy tervezzek és valósítsak meg egy olyan mozgatással egybekötött programozott rendszert, amely a hozzá csatlakoztatott érzékelő bizonyos paramétereit és az adott érzékelt tárgyra adott reakcióját megfelelő mintavételezéssel feldolgozza, rögzíti, majd pedig kiértékelésre megfelelő formában meg is jeleníti.
\end{abstract}

Kulcsszavak- National Instruments; myDAQ; LabVIEW; Reed; FESTO

\section{BEVEZETÖ}

A feladatom során közelítéskapcsolókat használtam fel, azok közül Reed-érzékelöket, valamint induktív közelítéskapcsolókat.

A Reed-szenzorok mágneses tér hatására kapcsolnak, hiszen az inert gázzal töltött üvegcsőben található ferromágneses érintkező nyelvek átmágneseződnek és vonzóerő ébred közöttük. Az 1. ábrán látható, hogy az érzékelők többféle kapcsolási tartománnyal is rendelkeznek, ami függ az előtte elhaladó mágnes pozíciójától, tengelyének irányától. [1] [2]
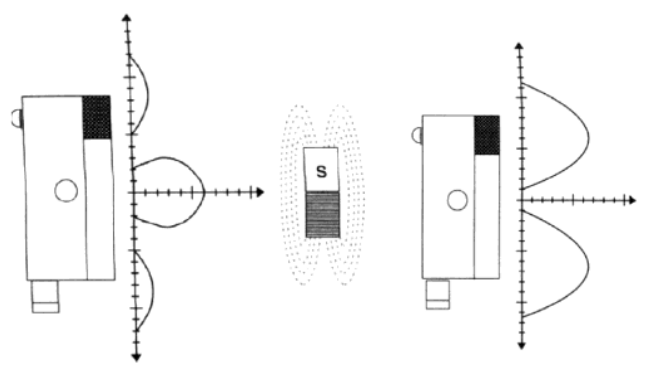

1. ábra: A Reed-érzélekők karakterisztikája [2]

Az induktív közelítéskapcsolók müködése egy LC kör rezgésállapotát befolyásolásán alapul, ahol az érzékelö elem egy nyitott vasmagú tekercs. Ha a közelben vezető tárgy található, akkor a keltett mágneses tér örvényáramokat hoz létre a fémtárgyban, azaz kapcsolni fog a közelítéskapcsoló. Az induktív szenzornál nincsen több kapcsolási tartomány. [3]

\section{AZ ÁLTALAM MEGALKOTOTT RENDSZER}

Az elkészített projekt során létre kellett hoznom egy olyan rendszert, amely tartalmazza az adatgyüjtő eszközt, a felhasznált érzékelőket, a mozgatásért felelős elektronikát és mechanikát, a szükséges tápellátást és a különböző eszközök vezérlésére és kiértékelésére megírt programot futtató számítógépet.

Adatgyüjtő eszközként a címben is megjelölt NI myDAQ készüléket használtam fel, szenzorok közül pedig kettő darab, eltérő kialakítású Reed-érzékelőt, illetve két különböző induktív közelítéskapcsolót csatlakoztattam felváltva a méréseim során.

A következőkben az általam megépített teljes rendszert kívánom bemutatni, részletezni azok alkotóelemeit, valamint ismertetni a közöttük kialakuló kapcsolati struktúrát.

A felépített rendszerem az alábbi tagokból áll:

- $\quad$ myDAQ adatgyüjtő eszköz (A),

- mozgató rendszer (B),

- $\quad$ motorvezérlő áramkör (C),

- feszültségosztó áramkör (D),

- $\quad$ érzékelő (E),

- tápegység $(\mathrm{F})$,

- $\quad$ számítógép $(\mathrm{G})$.

Az eszközök fennálló kapcsolatait a 2. ábra mutatja be. A mindkét végén nyíllal ellátott részek oda-vissza történő kommunikációra utalnak, míg a másik esetben csak egy irányba történő adat vagy feszültség áramlását jelzi.

A 24 V-os tápegység biztosítja a feszültséget az érzékelőnek és a motornak a motorvezérlő áramkörön át. Az érzékelő fekete és kék vezetékét csatlakoztattam a feszültségosztóba, amely a $24 \mathrm{~V}$ DC feszültségből körülbelül $10 \mathrm{~V}$ egyenfeszültséget hoz létre, így már biztonságosan csatlakoztatható a myDAQ eszköz analóg bemeneti portjaira, 
hiszen az analóg portok csak $\pm 10 \quad \mathrm{~V}$ közötti feszültség mérésére alkalmasak. Az adatgyüjtő eszköz felelős a motorvezérlő áramkör üzemeléséért, ami ezen keresztül a mozgatórendszert is müködésbe hozza. A mozgatórendszer végálláskapcsolói müködtetés esetén jelet küldenek a myDAQ eszköznek, ami másik irányba indítja el a motorokat, vagy teljesen megállítja a rendszer attól függően, hogy mennyi volt a mozgatások száma.

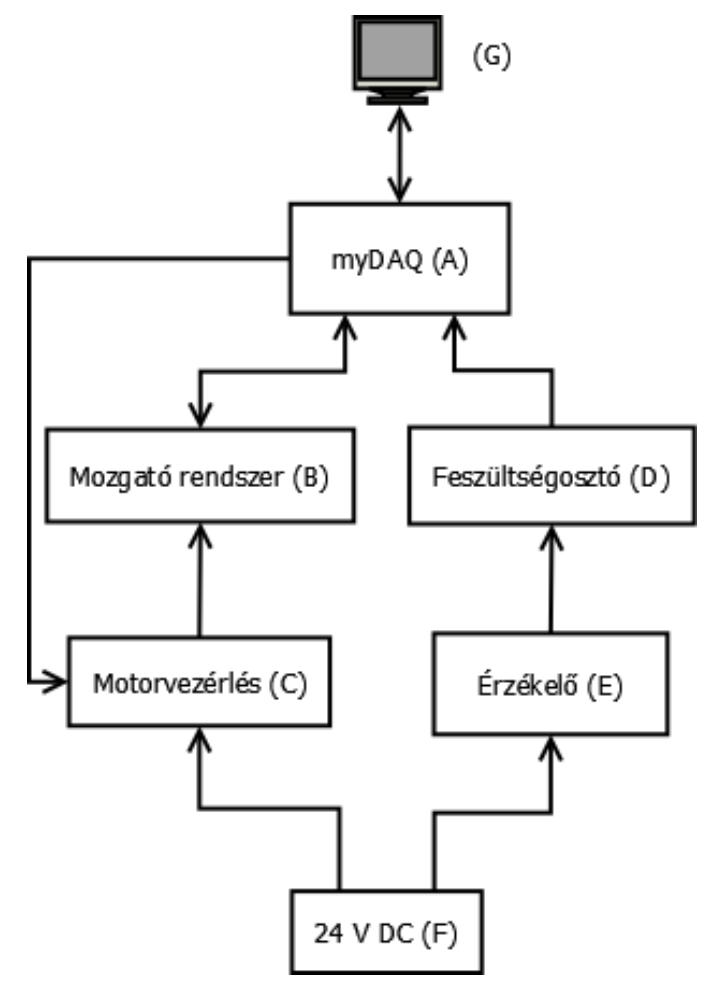

2. ábra: A rendszer sematikus felépítése

A fizikailag megépített tesztelő állomás modelljén (3. ábra) fontos helyet foglal el az érzékelö (E). A dolgozatom során az alábbi, tanszéki laborban fellelhető érzékelöket használtam fel:

- $\quad$ FESTO SME-8-K-LED-24,

- FESTO SMEO-4U-K-LED-24,

- $\quad$ Baumer IFRM 06P1503/S35L,

- Baumer IFRM 12P1701/S35L.

A FESTO cég által gyártott érzékelők egy belső Reedkontaktussal ellátott elektromos közelítéskapcsolók, amelyek 12-30 V DC feszültségek között üzemelnek és alaphelyzetben nyitott (NO - Normally Open) érintkezővel rendelkeznek.

A Baumer cég által forgalmazott szenzorok induktív közelítéskapcsolók, amely záró típusúak (NO), valamint 12-30 V DC tápfeszültségek között müködtethetőek.
Recent Innovations in Mechatronics (RIiM) Vol. 4. (2017). No. SI.

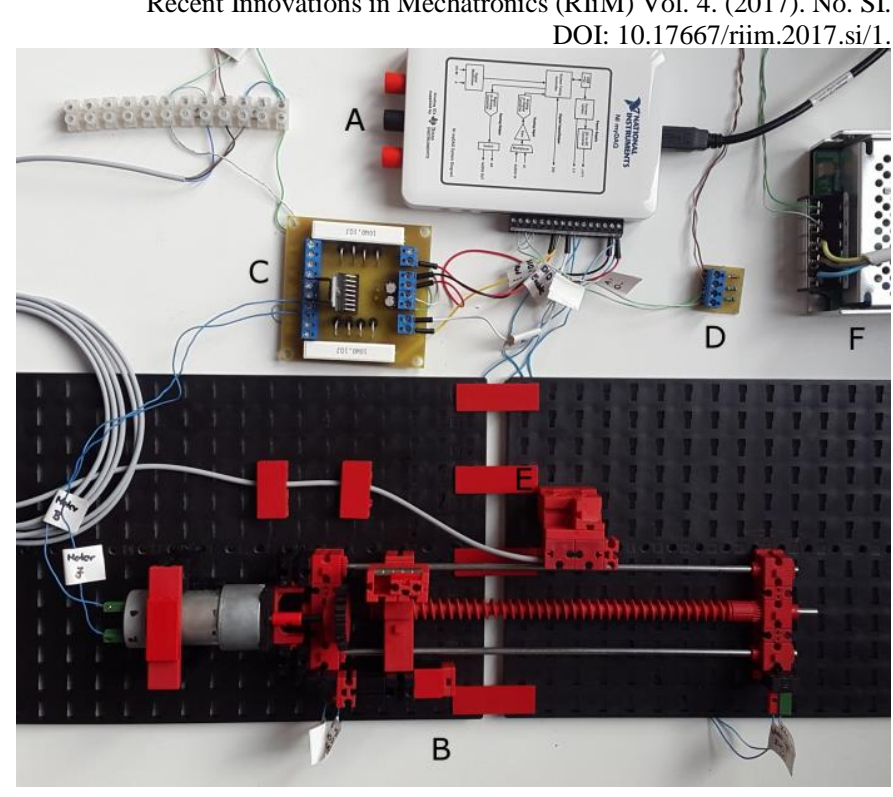

3. ábra: A megépített rendszerem

\section{A. NI myDAQ}

$\mathrm{Az}$ általam megépített rendszerben 2. ábrán és a 3. ábrán 'A'-val jelölt részen található az National Instruments myDAQ eszköz. Látható, hogy az adatgyüjtő összeköttetésben áll közvetett vagy közvetlen módon az összes részegységgel.

Az adatgyüjtő (A) közvetlen kapcsolatban van a számítógéppel, ezen fut az érzékelésért, a mozgatásért és kiértékelésért felelös program. Direkt kapcsolatban van a motorvezérlő egységgel (C), hiszen a programban meghatározott feltételek hatására ad jelet egyik vagy a másik irányba történő mozgatáshoz, illetve végállás esetén jelet küld az eszköznek a programon keresztül. Továbbá a feszültségosztón (D) keresztül összeköttetésben van az érzékelővel (E), hiszen a bemeneti feszültség $( \pm 10 \quad \mathrm{~V})$ tartománya miatt nem köthető rá közvetlenül a myDAQ analóg bementi portjaira.

\section{B. Szenzor mozgatórendszer}

Az érzékelések megvalósításához szükségem volt egy olyan rendszerre, amely a megfelelö és a müködés során ugyanolyan módon mozdítja el az érzékelni kívánt tárgyat a fixen elhelyezett érzékelő előtt, ehhez a tanszéki laborban található 'fischertechnik' építőelemeket használtam fel.

Lényeges volt még, hogy a mozgatni kívánt, érzékelendő tárgyat könnyen fel lehessen fogatni a mozgatott szánra, valamint mozgás közben ne lengjen ki a tárgy egyik oldalra sem, ezért mindkét oldalról egy-egy vezetősínt építettem a csigahajtás támogatására.

Szükség volt minden érzékelő számára egy befogóelemre, valamint egy, a szánra rögzíthető tárgybefogó eszközre, amely az ismétlődő, ellentétes irányú mozgatás ellenére is stabilan tartja a tárgyat. Mivel a Reed-érzékelők esetén a mágnest két különböző befogási pozícióban érdemes felhelyezni (elsőként az érzékelővel párhuzamos, azaz az északi pólusát a mozgatás irányára illesztve, majd pedig merőlegesen, amikor az északi 
pólus a szenzor felé mutat), ezért könnyen átszerelhető formát kellett kialakítani.

A két végálláskapcsoló benyomásához is létrehoztam a szán oldalain egy-egy ütközőfelületet, amelyre azért volt szükségem, mert a tengelyvégek miatt a csigasor nem tart ki egészen a végálláskapcsoló rögzítő eleméig.

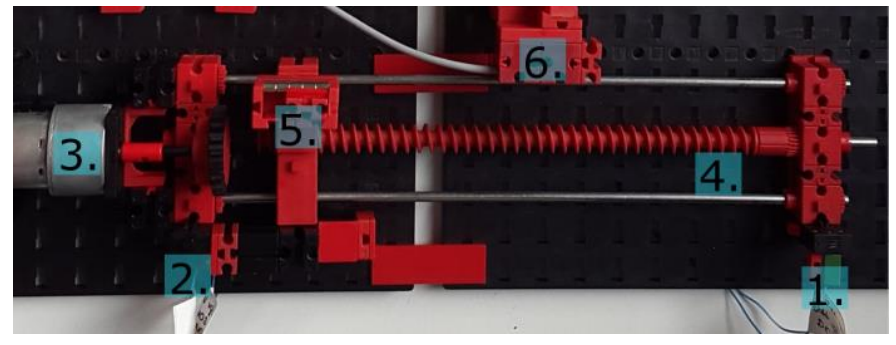

4. ábra: A mozgató mechanika

A 4. ábrán láthatóak a mozgatórendszer főbb részei:

1. Jobb végálláskapcsoló,

2. Bal végálláskapcsoló,

3. Motor,

4. Mozgás pályája,

5. Érzékelendő tárgy befogóegysége, szán,

6. Érzékelő tartóegysége.

További fontos egység még a motorvezérlő áramkör és a motor, illetve az érzékelő tápellátásáért felelős tápegység, amelyek elhelyezkedését a 3. ábra mutatja be, ahol 'C' és 'F' betükkel vannak jelölve.

A felhasznált végálláskapcsolók a 'fischertechnik' Morsetípusú kapcsolói, amelyeknek középső (1-es) csatlakozására a myDAQ +5 V-ját kapcsoltam, míg az alaphelyzetben nyitott (NO - Normally Open, 3-as) kontaktusára. A jobb oldali esetén a DIO4-es, míg a bal oldalinál a DIO3-as digitális bemenetét csatlakoztattam. Így ha a rendszer eléri valamelyik végállását, akkor az érintkező zár, tehát az $+5 \mathrm{~V}$-os jel a myDAQ felé továbbítódik. Ezt a bemenetet érzékelve a megírt programon belül megállítottam a további ugyanilyen történő mozgást, majd megfordítottam a mozgatás irányát, vagy leállítottam a folyamatot.

\section{Motorvezérlés}

A 24 V-os DC motor forgásirányának módosításához a feszültség polaritását kell megváltoztatni, ezért egy L298N típusú H-híd IC-t tartalmazó áramkört terveztem és valósítottam meg. A megtervezett áramkör két DC motor vezérlésére alkalmas, amelyeket egymástól függetlenül lehet ki- illetve bekapcsolni egy-egy erre dedikált bemenettel (Enable A, B). [6]

A megtervezett áramkörben kétféle tápellátást használtam. $\mathrm{Az}+5 \mathrm{~V}$ DC feszültség a myDAQ eszközéből érkezik, amely felelös a kapuáramkörök müködtetéséért, míg a +24 V DC feszültséget a külső tápegység látja el, ez a motor müködtetéséért felel.

Mivel eredetileg az IC két DC motor egyidejű hajtására képes, nekem azonban csak egy motorra volt szükségem, így nem használtam fel minden biztosított ki- és bemenetet. 'Out1', 'Out2' csatlakozásokra a motort kötöttem, míg 'Out3'ra és 'Out4'-re ebben az esetben semmit.

A már említett Enable ('EN_A', 'EN_B'), azaz engedélyező bemenet a két független H-híd feszültség alá kerüléséért felel. A felhasznált 'EN_A' konnektorra a myDAQ 'DIO0' portját csatlakoztattam.

A bemeneti oldalon sem vettem igénybe az összes csatlakozót. Az 'IN1' és 'IN2' bemenetek felelősek az 'A' motor egyik, illetve másik irányba való hajtásához, míg 'IN3' és 'IN4' a 'B' motort vezérlik. Ha 'IN1' bemenetre jel érkezik a myDAQ 'DIO1' portjából, akkor az elindítja a motort adott irányba, feltéve, ha az EN_A is jelet kapott közben. Azonos feltételek mellett 'IN2' kap jelet a 'DIO2' kimenetböl, akkor az ellenkező irányba fog forogni a motor. Mivel 'IN3' és 'IN4', valamint 'EN_B' a másik motor vezérléséért felelősek, így ezekre a bemeneteket nem használtam fel.

Ezeken felül rendelkezik még az áramkör motoronként egy feszültségmérésre is alkalmas csatlakozókkal, amelyeken így a motoron eső feszültséget lehet mérni.

\section{MOTORVEZÉRLŐ PROGRAMOM}

A teljes berendezés szoftveres oldalát a LabVIEW 2013-as verziójával készítettem el.

A program fejlesztése közben az első nagyobb rész a motor vezérléséért felelős egység. A létrehozott programrészlet, amely a mozgatásért felelős az 5. ábrán figyelhető meg. Mivel a motorvezérlő áramkör Enable (DIO0) bemenetére folyamatosan jelet kellett adnom, azonban az IN1 (DIO1) és IN2 (DIO2) portjai közül csak felváltva szükséges, ezért az egyik gyakran használt tervezési mintával oldottam meg, létrehoztam egy állapotgépet, amely különböző állapotokat tartalmaz, azonban ezek közül a rendszer egyszerre csak egy állapotban lehet és azok közötti váltások előre szigorúan meghatározottak, feltételekhez vannak kötve. [7]

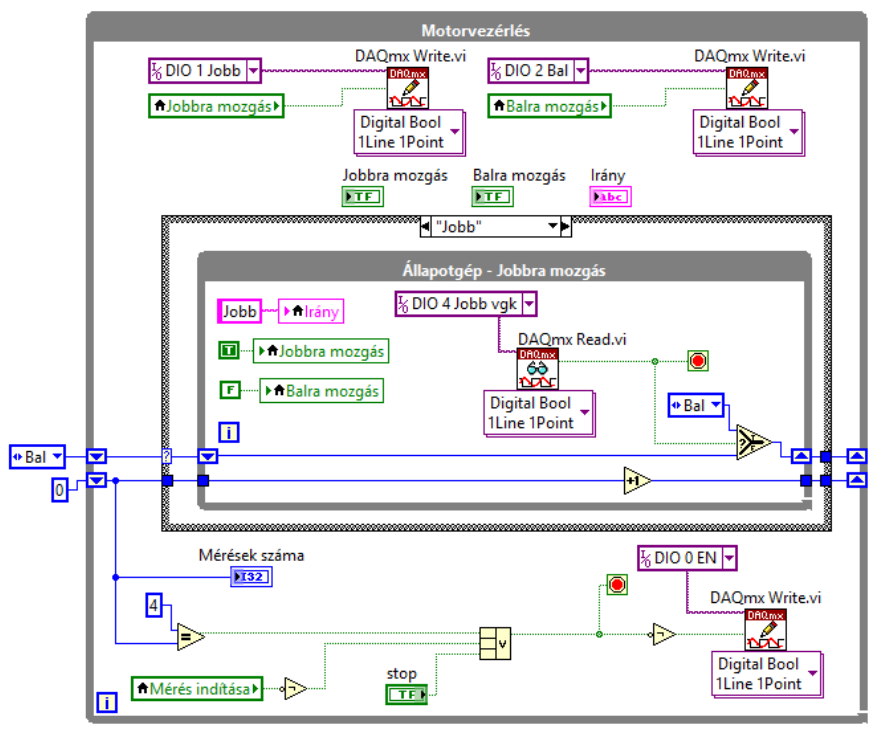

5. ábra: Motorvezérlő programrészlet 
A mozgatás elindítását az előlap 'Mérés' fülére kattintva lehet elindítani, hiszen a mérő és a mozgató funkcióknak párhuzamosan kell lefutniuk. Ha a 'Mérés indítása' kapcsoló már aktív volt az ablakváltáskor, akkor azonnal elindul, ellenkező esetben azonban csak a kapcsoló müködésbe hozásának pillanatában. Ha a mozgatás során kikapcsolom ezt, akkor csak az adott mozgási részfolyamatot fejezi be, majd valamelyik végállásban megáll.

A folyamat kezdetén a külső 'while' ciklushoz két 'shift register'-t adtam, amelyeket inicializáltam is 'Bal', illetve '0' kezdőértékkel. Ezeket a regisztereket abban az esetben kell használni, ha adatokat egy ismétlődő ciklus előző folyamataiból lehet csak elérni és felhasználni. Az inicializálás során a megadott nulla érték minden egyes folyamat során eggyel növekedni fog, valamint ez felelös a teljes ciklus megállításáért is. [19]

A Stop funkció végrehajtását összesen háromféleképpen tudjuk aktiválni, ezeket egy 'vagy' kapcsolat köti össze. Első esetben az inicializált nulla értékhez minden körben egyet hozzáadva eléri az elöre meghatározott értéket, jelen esetben az 5-öt, és ilyenkor igaz értéket továbbít a leállításnak. Második esetben akkor, ha a 'Mérés indítása' kapcsoló inaktív (kikapcsolt) állapotba kerül. Ebben az esetben a negáltja, azaz igaz érték fog továbbadódni. Utolsóként pedig a feltüntetett 'Stop' tudja megállítani a mozgatásért felelős ciklust.

A motorvezérlö áramkör 'Enable' bemenete a myDAQ DIO0 portján keresztül vezérelhetö. Ehhez a LabVIEW DAQmx Write.vi eszközét használtam, amelyet úgy állítottam be, hogy digitális jelet küldjön ki a beállított csatornán. Tehát ha igaz, akkor a kimeneten van feszültség, ha hamis, akkor nincs. A bemenetre pedig a folyamat megállításáért felelős jel negáltját kötöttem. Azaz, amíg az előbb felsorolt feltételek közül egyik sem teljesül (hamis), addig a kimeneten igaz érték kerül, így feszültség alatt lesz. Azonban ha valamelyik feltétel igaz lesz, leáll a folyamat és a kimenetről elveszi a feszültséget.

A program felső harmadában találhatóak további DAQmx Write.vi-ok, amelyek a két irányba való mozgatás létrehozásáért felelősek. A beállított csatornán (DIO1 vagy DIO2) akkor lesz feszültség, ha a bemeneten található boolean típusú lokális változó ('Jobbra mozgás', 'Balra mozgás') igaz értéket vesz fel.

$\mathrm{Az}$ ellentétes irányú mozgáshoz szükséges állapotgépet egy 'case' struktúra hajtja végre. Ehhez szükségem volt továbbá egy 'enum' típusú konstansra, amelynek megadott állapotai lesznek az egyes 'case'-ek. Három állapotot hoztam létre, amelyek a 'Stop, Default', a 'Jobb' és a 'Bal'. Az első esetben két fö rész található, egyrészt hamis értékeket ad a 'Jobbra mozgás' és 'Balra mozgás' lokális változóknak, így azokon nem lesz feszültség kimenet, valamint a 'Mérés indítása' kapcsoló állapotától függően ebben az állapotban tartja a programot, illetve ha a kapcsoló aktív, akkor mozgásba hozza.

Az 5. ábrán látható az az állapot, ami a jobbra mozgatásért felelős. Ebben az esetben a lokális változók közül a jobbra mozgató igaz, míg a balra hamis értéket kap. A DAQmx Read.vi blokk figyeli a DIO4-re csatlakoztatott jobb végálláskapcsoló jelét, tehát amíg nincs jel, addig nem lesz a ciklus leállítva és a program marad ebben az állapotban. Azonban ha jel érkezik, akkor az állapotgép átugrik a 'Bal' állapotba és ez a ciklus megszakad. Továbbá a shift register értékéhez hozzáadódik egy, amely majd felelős lesz a teljes motorvezérlő ciklus megállításáért.

\section{MÉRÉS ÉS AZ ADATOK KIMENTÉSE}

A mérések elvégzése során a 6 . ábrán látható lépéseket hajtottam végre.

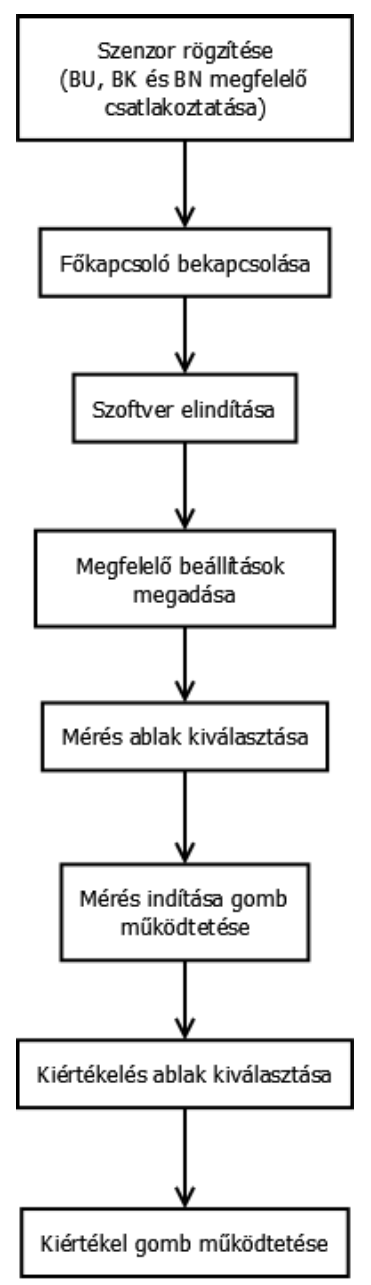

6. ábra: A mérési folyamat során elvégzett lépések

A mérésért felelős programrészlet során a DAQmx Create Virtual Channel.vi segítségével egy analóg bemeneti (AI) csatornát hoztam létre, ahol feszültséget lehet mérni. Ehhez szükség volt egy, az előlapon is megjelenő vezérlő létrehozására (Mérés csatornája), ahol a mérés fizikai csatornáját lehet kiválasztani, valamint be kell állítani a szenzor tápfeszültségét, amit a feszültségosztó arányának megfelelően redukáltam. A DAQmx Timing.vi-t felhasználva a vezérlők segítségével beállítottam a mérés során felhasznált órajelet, a mintavételezés frekvenciáját, valamint a csatornánkénti minták számát, majd a DAQmx Start Task.vi futásba állítja a mérési folyamatot. [8] 
A 'while' cikluson belül történik a folyamatos mérés az elöző beállítások alapján, a kijelzés, valamint az adatok *.tdms fájlba történő exportálása. A cikluson kívül található a DAQmx Clear Task.vi, amely megállítja és törli a megnyitott feladatot, ezáltal felszabadítja azokat az erőforrásokat, amiket az adott tevékenység felhasznált.

\section{KIÉRTÉKELÉS}

A Front Panelen található harmadik részegység a mért adatok kiértékeléséért felelős. A 'Kiértékel' kapcsoló aktív állapota esetén a program a 'TDMS Open' felhasználásával megnyitja a mentett fájlt a 'Mentés helye' kontrol lokális változójának segítségével. Ezután a program kiolvassa a 'TDMS Read' segítségével az adatsort és a mérés során felhasznált csatornát, majd a 'TDMS Get Properties' blokk alkalmazásával a logolt fájl tulajdonságait gyüjtöttem ki. A 'cluster' első három eleme tartalmazza a létrehozott fájl nevét, a mérés során belefüzött szenzor típusát és a mérés idejét.

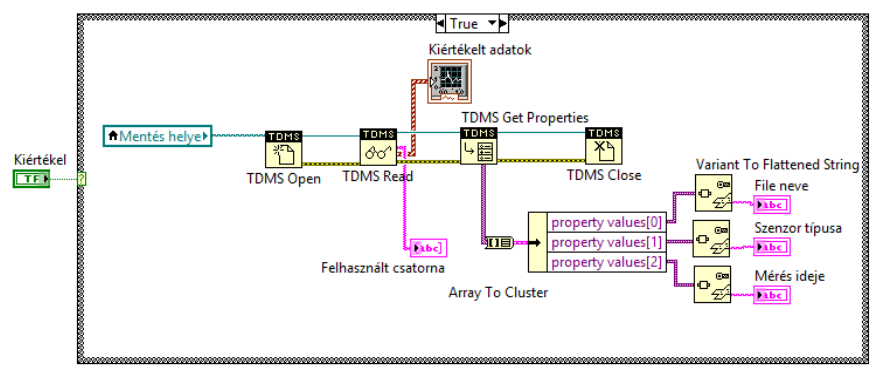

7. ábra: Kiértékelő programrészlet

A kiértékelési folyamat valójában nem igényel rá csatlakoztatott myDAQ eszközt, hiszen csak a *.tdms fájlra van szüksége a grafikon megalkotásához.

A továbbiakban a kiértékelés közben kapott grafikonokat kívánom bemutatni, illetve elemezni. A méréseket minden érzékelő esetén többször elvégeztem, hogy megbizonyosodjak róla, hogy nem történt mérési hiba, mint például a mágnestartó egység összeütközött-e a szenzorral. Továbbá azokban az esetekben, ahol több azonos típusú érzékelő is a rendelkezésemre állt, ott azonos pozícióban egymás után többször is elvégeztem különböző szenzoroknak a mérését.

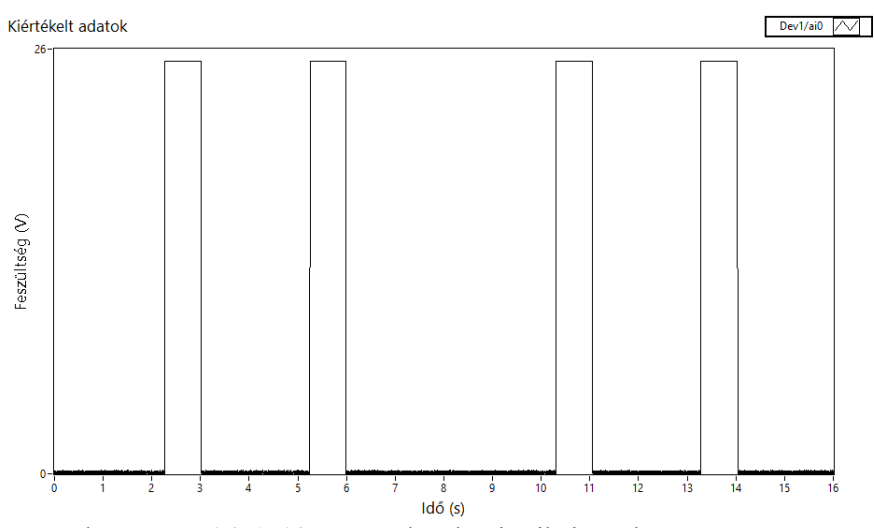

8. ábra: IFRM 06P1503 szenzor karakterisztikája párhuzamos esetben.

A 8. ábra megmutatja a Baumer IFRM 06P1503/S35L típusú szenzora esetén mért kapcsolási karakterisztikát. Az első esetben párhuzamosan helyeztem el a mágnest az érzékelési felületéhez képest. Látható, hogy amíg az érzékelő a tárgy elött elhalad, kapcsol, tehát feszültség mérhetö rajta. Amíg viszont a testtől távolabb helyezkedik el, tehát kapcsolási távolságon kívül, abban az esetben pedig közel $0 \mathrm{~V}$ feszültség mérhető.

A következő esetben ugyanezt az érzékelőt felhasználva, a mérésemet úgy változtattam meg, hogy a mágnest az érzékelési felületére merőlegesen helyeztem el, így a 9. ábrán megfigyelhető jelleggörbét kaptam eredményül. A két ábra valójában csak annyiban tér el egymástól, hogy ebben a helyzetben a mágnes rövidebbik oldala esett az érzékelö irányába, így sokkal rövidebb ideig maradt kapcsolási távolságán belül.

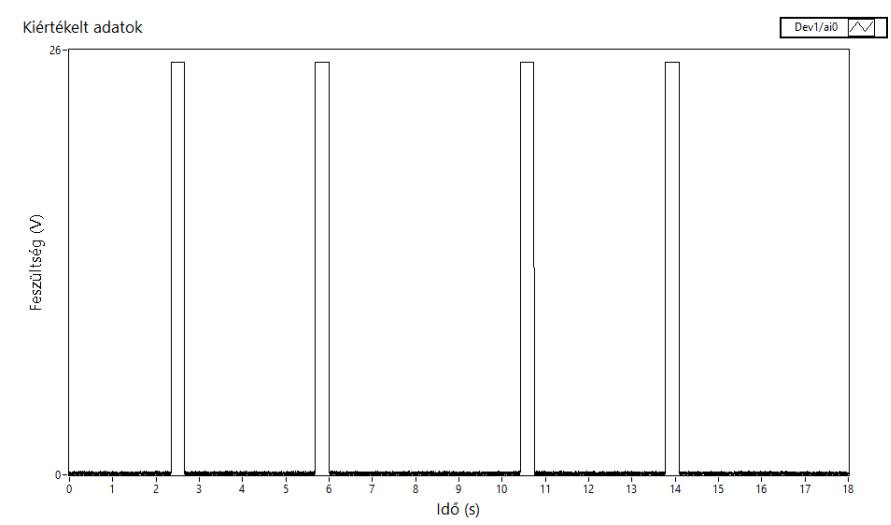

9. ábra: IFRM 06P1503 karakterisztikája merőleges esetben

A feladatomban a valódi kihívást a Reed-érzékelők karakterisztikái jelentették, hiszen ahogy korábban, még a 1 . ábrán látható volt, hogy a szenzort oldalirányból közelítve kettő vagy akár három be- és kikapcsolást is eredményezhet bizonyos elrendezések esetén.

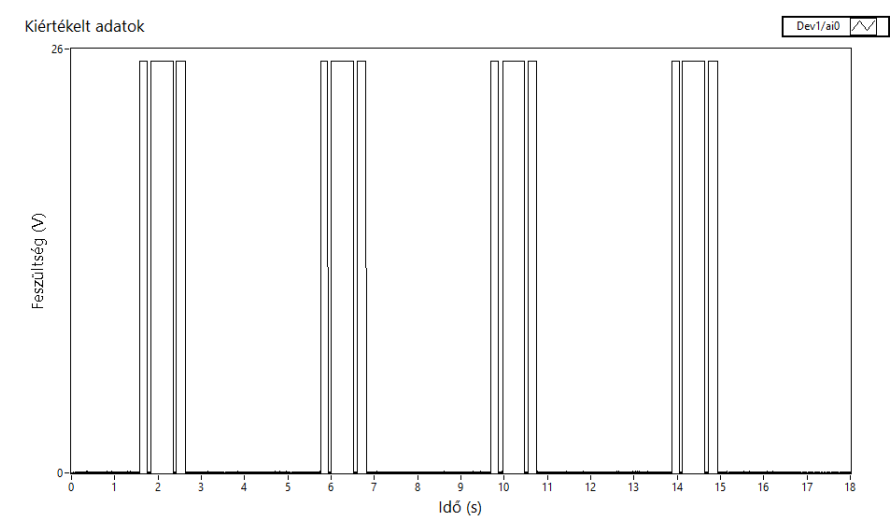

10. ábra: SME-8-K érzékelő párhuzamos elhelyezés esetén

Az első ilyen típusú érzékelő a FESTO SME-8-K-LED-24 volt, amelyet a mágnessel párhuzamosan helyeztem el. Több mérés elvégzése után a 10. ábrán megfigyelhető kapcsolási karakterisztikát tudtam a felhasznált eszközeimmel kimutatni. Megfigyelhető benne a Reed-érzékelők jellegére tipikusan jellemző hármas osztottság, amely a háromszori be- és kikapcsolás eredményez. 


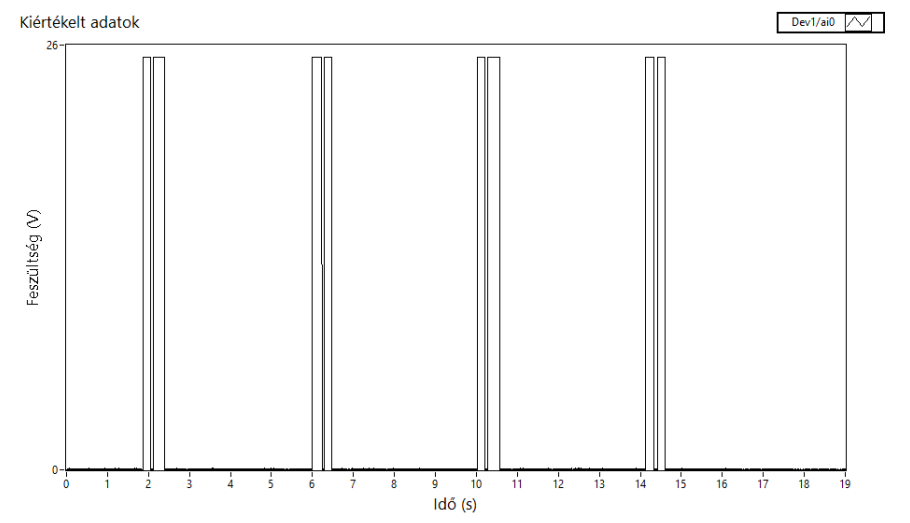

11. ábra: SME-8-K merőleges elhelyezés esetén

A FESTO SME-8-K érzékelő felhasználásával, a mágnes merőleges elhelyezése esetén a 11. ábrán látható jelleggörbét tudtam meghatározni. Ez alátámasztja a Reed-szenzorok névleges karakterisztikáját, amely szakirodalmi adatok alapján a 2. ábrán látható.

A 12. ábrán látható a FESTO SMEO-4U-K-LED-24 típusú érzékelőjének vizsgálata, ahol a felhasznált mágnes merőlegesen lett rögzítve. Megfigyelhető, hogy valójában nincs jelentős eltérés az előző ábrával összevetve.

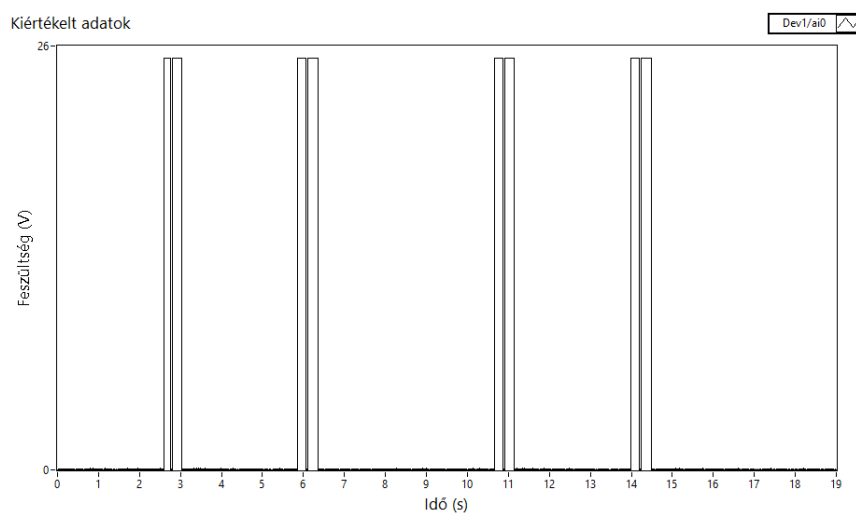

12. ábra: SMEO-4U merőleges elhelyezés esetén

További méréseket végeztem ezzel a Reed-érzékelővel, ám arra a következtetésre jutottam, hogy a két szenzor mért értékeinek grafikonon kijelzett képei között nincs jellegbeli eltérés, ezért nem ismertetem külön a mágnes mindkét pozíciójában kapott adatsorom. $\mathrm{Az}$ általam alkotott mérőrendszer segítségével tehát képes a felhasználó a bizonytalanul müködő szenzorokat kiszürni, és továbbá fel lehet használni az akár hibásnak tünő szenzorok vizsgálata során is.

A méréseim alapján arra a következtetésre jutottam, hogy az általam írt program és a felhasznált eszköz is képes olyan sebességü mintavételezést végrehajtani, hogy ezek az érzékelőre (Reed) jellemző sajátos karakterisztikák is kimutathatóak legyenek.

A 8. és 9. ábrák alkalmával bemutatott induktív közelítéskapcsolók azonban nem rendelkeznek ehhez hasonló jelleggörbével, így ezekkel a szenzorokkal be tudtam mutatni, hogy a feszültségértékek bizonyos ideig $0 \mathrm{~V}$-ra esését nem a készülék vagy a program hibája okozza, hanem valóban ki- és be kapcsol a szenzor nagyon rövid idö alatt.

\section{VI. ÖSSZEFOGLALÁS}

Az ipari szenzorokat tesztelő állomás modell fejlesztése közben sikerült egy olyan rendszer kialakítanom, amely teljesíti az összes elöre definiált elvárást. Sikerült a berendezésemet viszonylag kicsi és kompakt méretüre megépítenem. Az irányító programomat felhasználóbarát, könnyen kezelhető és látványos a megjelenítésüre igyekeztem megalkotni. A mérő eszközeimmel az ezred-másodpercenként elvégzett mérés eredményeit is képes vagyok részleteibe menően megtekinteni, elemezni.

A felépített rendszer további fejlesztésekkel még pontosabbá, hatékonyabbá és egyszerübbé válhat. A teszt szoftvert szeretném magnetoinduktív érzékelőkkel is tesztelni, hogy ott is az elvártnak megfelelően alakulnak-e a karakterisztikák, továbbá precízebb, pontosabb befogóeszköz tervezésével kiküszöbölhetőek lennének a mérés során az érzékelők elmozdulásából adódó esetleges hibák. Ezeket a rögzítőket akár 3D nyomtatással el lehetne készíteni, amelyek kompatibilis a jelenlegi rögzítő hornyokkal. A jövőben egy összetettebb feldolgozást is szeretnék kifejleszteni, amely nem a felhasználóra bízza a grafikon kiértékelését, hanem azt automatikusan elvégzi és kijelzi.

A rendszer működés közben megtekinthető: https://youtu.be/qGIrtDw4BOA

\section{KÖSZÖNETNYILVÁNÍTÁS}

Szeretném köszönetemet kifejezni konzulensemnek, Dr. Tóth Jánosnak, aki hasznos tanácsaival, szaktudásával és észrevételeivel segítette munkámat, biztosította számomra a szükséges eszközöket, valamint szakdolgozatom elkészítéséhez a DE MK Villamosmérnöki és Mechatronikai Tanszékén a helyszínt.

\section{HIVATKOZÁSOK}

[1] Dr. Tóth János, „Mérés- és Irányítástechnika I.”. [Előadás]. 2011.

[2] Krámli György, „FESTO Szenzorika,” FESTO Kft., Budapest, 2007.

[3] Bánlaki Pál, Lovas Antal, „Szenzorika és anyagai”, Budapest: Typotex Kiadó, 2012.

[4] Újvári Sándor, Magyarkuti András, „NI myDAQ használati utasíitás és specifikáció,” [Online dokumentum]. Hozzáférés:

http://sukjaro.eu/ELFT-NI-palyazat/myDAQ_magyar.pdf. [Letöltve: 2016. november 22.]

[5] National Instruments, „NI myDAQ User Guide,” augusztus 2014.. [Online dokumentum]. Hozzáférés: sttp://www.ni.com/pdf/manuals/373060f.pdf. [Letöltve: 2016. november 22.].

[6] STMicroelectronics, „L298 Dual full-bridge driver,” január 2000.. [Online dokumentum]. Hozzáférés: https://www.sparkfun.com/datasheets/Robotics/L298_H_Bridge.pdf. [Letöltve: 2016. november 23.].

[7] National Instruments, LabVIEW Core 1 Participant Guide, Austin, Texas: National Instruments, 2014.

[8] National Instruments, LabVIEW Core 2 Participant Guide, Austin, Texas: National Instruments, 2014. 
Recent Innovations in Mechatronics (RIiM) Vol. 4. (2017). No. SI.

DOI: $10.17667 /$ riim.2017.si/1. 